\title{
Combined Application of Biochar with Fertilizers Influence available Nitrogen, Phosphorus and Potassium Quantity in Soil
}

\author{
Rema Barman $^{1 *}$, Akul Gupta ${ }^{1}$ and Geeta Kandpal ${ }^{2}$ \\ ${ }^{1}$ Department of Agronomy, School of Agriculture, Lovely Professional University, \\ Phagwara, 144411, Punjab, India \\ ${ }^{2}$ Department of Agronomy, Lovely Professional University, Phagwara, 144411, Punjab, India \\ *Corresponding author
}

\section{A B S T R A C T}

\begin{tabular}{|l|}
\hline Ke y w o r d s \\
Biochar, Inorganic, \\
Soil chemical \\
parameter, Wheat
\end{tabular}

\section{Introduction}

Soil is the back bone of agriculture which having all the macro and micro essential nutrient which is most important for plant growth and development. Soil physical condition has direct impact on soil productivity for crop production. The soil having good structure, porosity, bulk density provide good medium for growth of beneficial microorganism which helps to increase nutrient retention in soil (Aslam et $a l ., 2014)$. Soil organic matter plays vital role in this nutrients availability in soil. Organic matter improves soil porosity, soil structure, soil water holding capacity, boast up some essential nutrients which helps to increase crop yield and soil productivity. The current situation is that because of high input method of crop cultivation, top soil gets deteriorated as a result losses of soil fertility. To improve soil health need to increase the soil available nutrient content. For this purpose integrated use of organic and inorganic amendments is the best way to maintain soil health (Vanlauwe et al., 2004). Organic fertilizer like manure, FYM, poultry manure, slurry generally are used but it is having high 
decomposition rate so need to use those organic manure which having lower decomposition rate for longer period of time (Aslam et al., 2014; Palm et al., 2001).

Biochar is a combination of two words one is "Bio" that means biomass and another one is "Char" that means charcoal (Nartey et al., 2014). It is a solid and high carbon compound in nature. It is made by Pyrolysis. Pyrolysis is a process which known as thermal decomposition of biomass (Aslam et al., 2014). During the biochar production all the biomass install in Pyrolysis chamber under low oxygen condition. It is having more surface area, negative charged surface which will hold the cations from the soil (Dume et al., 2017). Biochar addition expands the porosity in soil. Porosity implies space between two particles present in soil (Bhattacharjee et al., 2015). The biochar treatment were found to build the shoot biomass, root biomass, plant tallness and number of leaves in all the cropping cycles in contrast with no biochar treatment (Gebremedhin et al., 2015). Since biochar draws in and holds soil supplements, it conceivably diminishes fertilizer necessities. As a result, fertilization costs are minimized and fertilizer (organic or chemical) is retained in the soil for longer. On the other hand it also helps to increase the soil $\mathrm{K}$ dissolving bacteria which help to increase soil available potassium contents in soil (Wang et al., 2018).

\section{Materials and Methods}

\section{Experiment area}

The trial was directed at the Agricultural research farm of Lovely Professional University, Phagwara. The cultivated area is geologically occupied at 31 degree 22 minutes and 31.81 seconds' north scope and 75 degree and 23 minutes and 3.02 seconds' east longitude with a height of around 252 meters over the ocean level. This territory falls under the trans-gangetic plain of agroclimatic zone of the Punjab state.

\section{Experimental discussion}

The trial was conducted on pot were arranged in completely randomized design with three replication. The hybrid variety of wheat HD2967, obtained from Wheat Research Station, Punjab Agriculture University, Ludhiana, Punjab for Combined application of biochar with fertilizers influence available nitrogen, phosphorus and potassium quantity in soil. Different pots were treated with different level of biochar and fertilizers viz., $\mathrm{T}_{1}(100 \% \mathrm{RDF}), \mathrm{T}_{2}$ (3\% Biochar+50\% RDF),

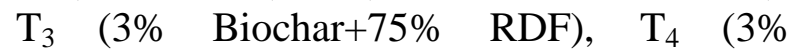
Biochar+100\% RDF), $\mathrm{T}_{5}$ (5\% Biochar+50\% $\mathrm{RDF}), \mathrm{T}_{6}\left(5 \%\right.$ Biochar+75\% RDF), $\mathrm{T}_{7}(5 \%$ Biochar+100\% RDF) with control. The observation was recorded at 30, 60 and 90 days after sowing with different soil chemical parameter like soil available nitrogen $(\mathrm{mg} / \mathrm{kg})$, soil available phosphorus $(\mathrm{mg} / \mathrm{kg})$, soil available potassium $(\mathrm{mg} / \mathrm{kg})$.

\section{Experimental analysis}

Data were analysed by using SPSS 22 and Microsoft excel. Analysis of variance (ANOVA) namely biochar with inorganic fertilizer with seven treatments were performed to see the significant difference on soil chemical parameters. Mean separation was done by using least significant difference after the treatment was found significant at $\mathrm{p}<$ 0.05 .

\section{Results and Discussion}

\section{Soil available nitrogen $(\mathrm{mg} / \mathrm{kg})$}

Effect of biochar with recommended dose of fertilizer and their combination on soil 
available nitrogen was studied in wheat variety HD2967 during the year 2017-18. The data was recorded at 30, 60 and 90 DAS. It is evident that the soil nitrogen was highest in $\mathrm{T}_{3}$ (17.76) at 30 DAS. The soil nitrogen was minimum in $\mathrm{T}_{1}(12.20)$ at $30 \mathrm{DAS}$, non significantly, with $\mathrm{T}_{3}$ as compare to control. At 60 days after sowing the available nitrogen was increased by 48.03 in $\mathrm{T}_{3}$ and 45.63 in $\mathrm{T}_{6}$. The minimum results were shown in $T_{1}$ (27.86). The result which estimated at 90 days after sowing it also give same result like 60 DAS. The increment of values was in T3 and T6 as early discussed and minimum value was in $\mathrm{T}_{1}$ as compare to control. After considered all the result which from 30 DAS to 90 DAS in available nitrogen was increased in $\mathrm{T}_{3}$ which was combination of $3 \%$ biochar $+75 \%$ RDF. Gao et al., conclude that in natural process microorganism oxidized ammonia and converted into nitrate which makes soil nitrogen available for plant growth but after application of biochar it increases soil ammonia oxidizing micro organism in soil. Nelissen et al., 2012; Song et al., 2013 also conclude same result (Fig. 1).

\section{Soil available phosphorus (mg/kg)}

Effect of biochar with recommended dose of fertilizer and their combination on soil available Phosphorus ( $\mathrm{mg} / \mathrm{kg}$ ) was studied in wheat variety HD2967 during the year 201718. The data was recorded at 30, 60 and 90 DAS (Figure 2). It is evident that the higher soil available phosphorus found in $\mathrm{T}_{3}$ and $\mathrm{T}_{5}$ with the value of $24.42 \mathrm{mg} / \mathrm{kg}$ and 22.40 $\mathrm{mg} / \mathrm{kg}$ and the lowest available phosphorus found in $\mathrm{T}_{1}(19.13)$ as compare to control at 30 days after sowing. On the other hand after application of biochar with recommended dose the soil available phosphorus was highest in $T_{3}$ (32.43) and $T_{7}$ (31.16) at 60 days after sowing and the lowest value was found in $T_{1}$. The soil available phosphorous also give satisfactory result in $T_{3}$ and $T_{6}$ with the value of $38.65 \mathrm{mg} / \mathrm{kg}$ and $37.54 \mathrm{mg} / \mathrm{kg}$ at 90 days after sowing. In this case also the minimum value was in $\mathrm{T}_{1}$ as compare to control. So from the above discussion can conclude that biochar helps to increase $\mathrm{P}$ availability in soil. Dume et al., 2017 reported that after application of biochar in acid and calcareous soil helps to minimize $P$ insolubility by absorbing the cations. Same result also concludes by the Borno ML et al., 2018. It can be said that biochar application helps to increase $\mathrm{P}$ in soil and also helps to maintain sustainability.

\section{Soil available potassium (mg/kg)}

Effect of biochar with recommended dose of fertilizer and their combination on soil available potassium $(\mathrm{mg} / \mathrm{kg})$ was studied in wheat variety HD2967 during the year 201718. The data was recorded at 30, 60 and 90 DAS (Figure 3). It is revealed that the highest soil available potassium was present in $\mathrm{T}_{3}$ (48) and $\mathrm{T}_{7}$ (46) at 30 days after sowing while $\mathrm{T}_{1}$ having very less quantity of soil available potassium as compare to control. The soil available potassium also gives better result in $\mathrm{T}_{3}$ and $\mathrm{T}_{7}$ at 60 and 90 days after sowing. The value was 53 and 54 at 60 DAS respectively with lowest value in $\mathrm{T}_{1}$ as compare to control. Wang et al., 2018 conduct an experiment to check the effect of biochar application on potassium dynamics of soil resulted that after application of biochar helps to increase the $\mathrm{K}$ dissolving bacteria in soil which increase the microbial activity as a result more potassium fixation by the micro organism in soil which helps to increase soil available potassium. On the other hand Gao et al., (2018) reported that biochar with high $\mathrm{pH}$, more surface area, more surface negative charge, and higher charge density has a greater ability to adsorb cations per unit carbon than other soil organic materials which helps to make unavailable form to available form of potassium in soil non significantly. 
Fig.1 Effect of combined application of biochar and fertilizers in soil available nitrogen

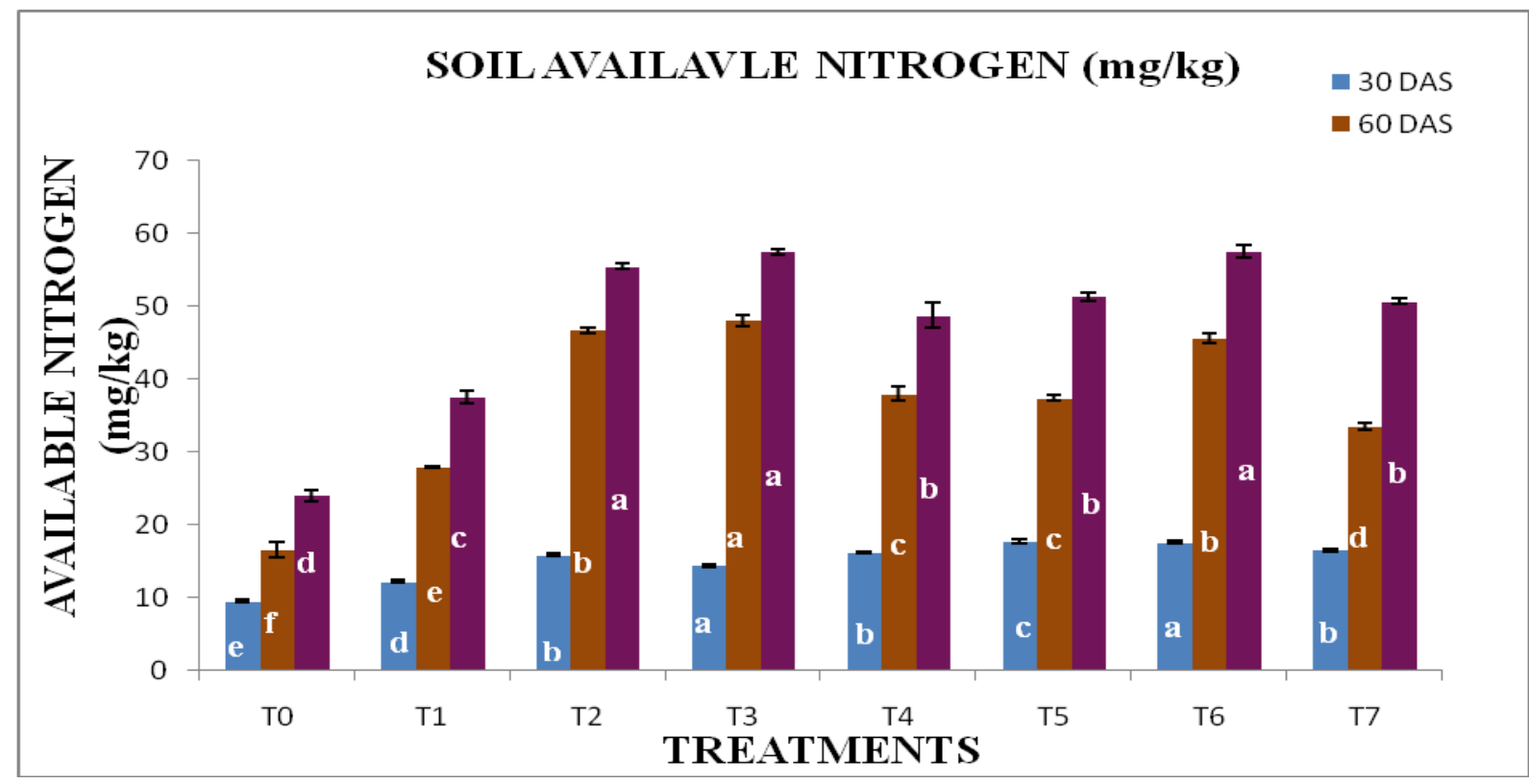

Where, DAS = Days after sowing, Data are in the form of mean \pm SEM at $\mathrm{p}<0.05$. The mean followed by different letters was significantly different at $\mathrm{p}<0.05$ according to DMRT for separation of means. $\mathrm{T}_{0^{-}}$control; $\mathrm{T}_{1^{-}} 100 \%$ RDF; $\mathrm{T}_{2}-3 \%$ biochar $+50 \%$ RDF; $\mathrm{T}_{3}-3 \%$ biochar $+75 \%$ RDF; $\mathrm{T}_{4}-3 \%$ biochar $+100 \%$ RDF; $\mathrm{T}_{5}-5 \%$ biochar + $50 \%$ RDF; $\mathrm{T}_{6}-5 \%$ biochar $+75 \%$ RDF $; \mathrm{T}_{7}-5 \%$ biochar $+100 \% \mathrm{RDF}$

Fig.2 Effect of combined application of biochar and fertilizers in soil available phosphorus

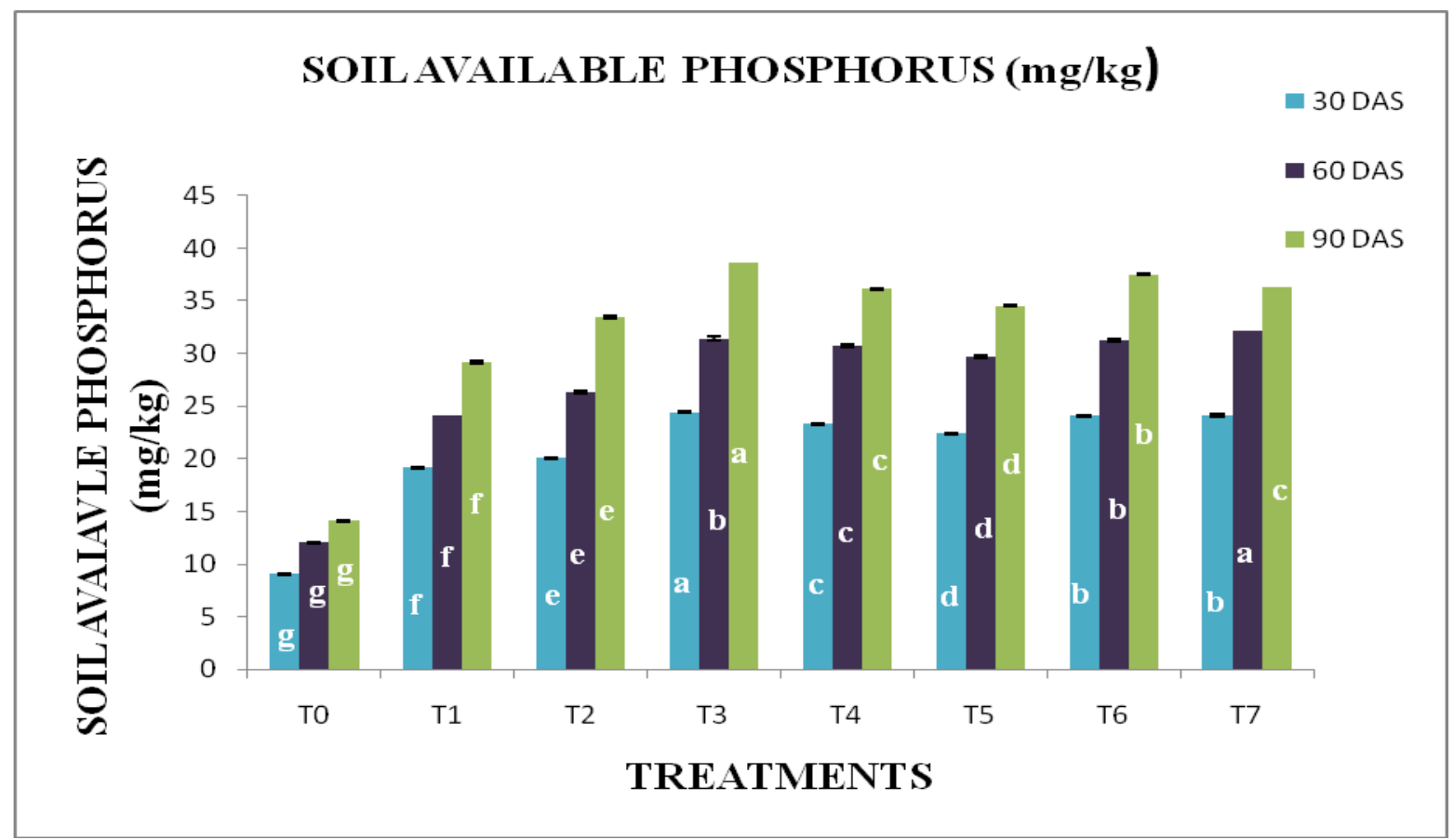

Where, DAS $=$ Days after sowing, Data are in the form of mean \pm SEM at $\mathrm{p}<0.05$. The mean followed by different letters was significantly different at $\mathrm{p}<0.05$ according to DMRT for separation of means. $\mathrm{T}_{0^{-}}$control; $\mathrm{T}_{1^{-}} 100 \%$ RDF; $\mathrm{T}_{2}-3 \%$ biochar $+50 \%$ RDF; $\mathrm{T}_{3}-3 \%$ biochar $+75 \%$ RDF; $\mathrm{T}_{4}-3 \%$ biochar $+100 \%$ RDF; $\mathrm{T}_{5}-5 \%$ biochar + $50 \%$ RDF $; \mathrm{T}_{6}-5 \%$ biochar $+75 \%$ RDF $; \mathrm{T}_{7}-5 \%$ biochar $+100 \%$ RDF 
Fig.3 Effect of combined application of biochar and fertilizers in soil available potassium

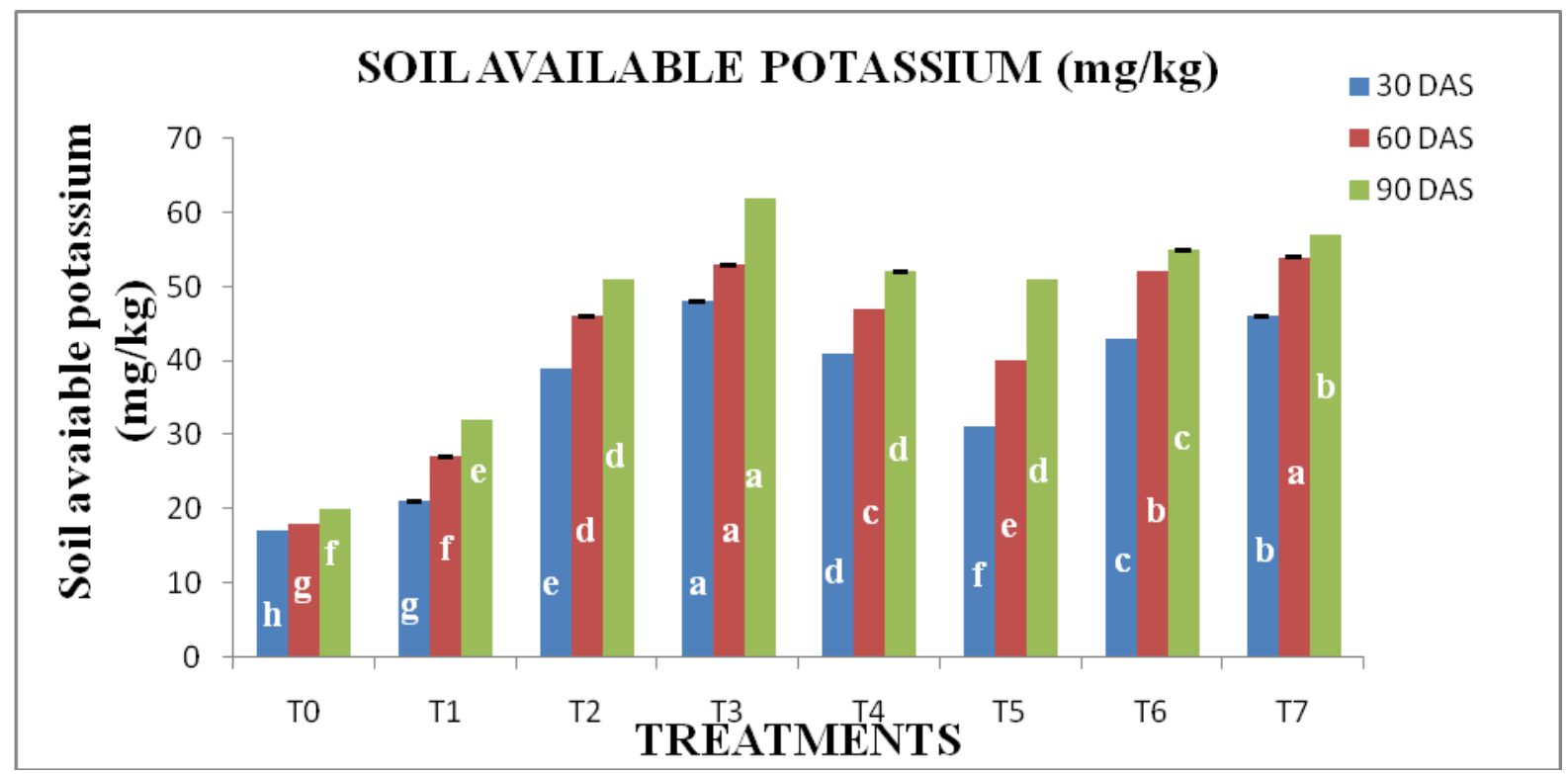

Where, DAS $=$ Days after sowing, Data are in the form of mean \pm SEM at $\mathrm{p}<0.05$. The mean followed by different letters was significantly different at $\mathrm{p}<0.05$ according to DMRT for separation of means. $\mathrm{T}_{0^{-}}$control; $\mathrm{T}_{1^{-}}-100 \%$ $\mathrm{RDF} ; \mathrm{T}_{2-}-3 \%$ biochar $+50 \%$ RDF $; \mathrm{T}_{3}-3 \%$ biochar $+75 \%$ RDF $; \mathrm{T}_{4}-3 \%$ biochar $+100 \%$ RDF $; \mathrm{T}_{5}-5 \%$ biochar $+50 \%$ $\mathrm{RDF} ; \mathrm{T}_{6}-5 \%$ biochar $+75 \% \mathrm{RDF} ; \mathrm{T}_{7}-5 \%$ biochar $+100 \% \mathrm{RDF}$

In conclusion, the experiment emphasizes an overview of specific knowledge about biochar interaction in soil. The application of biochar increases the soil available nitrogen, phosphorus, and potassium because of its porous structure which helps to increase soil nutrient retention. Incorporation of biochar increase the ammonium absorbing bacteria and potassium dissolving bacteria in cultivate soil. It not only increase the microbial activity also helps to absorb the cations which may helps to increase the phosphorus availability in soil. The main purpose of this review is to gives knowledge about biochar, and to recommend for research needs to systematically understand about the biochar Nutrient interaction with soil over a longer period of time.

\section{References}

Abdollahi, M. R., Zaefarian, F., Hunt, H., Anwar, M. N., Thomas, D. G., and Ravindran, V., 2019. Wheat particle size, insoluble fibre sources and whole wheat feeding influence gizzard musculature and nutrient utilisation to different extents in broiler chickens. "Journal of animal physiology and animal nutrition”, 103(1), 146-161.

Abewa, A., Yitaferu, B., Selassie, Y., and Amare, T., 2014. "The role of biochar on acid soil reclamation and yield of Teff (Eragrostis tef [Zucc] trotter) in northwestern Ethiopia," Journal of Agricultural Science, 6: 2-9.

Abrishamkesh, S., Gorji, M., Asadi, H., Bagheri-Marandi, G.H., Pourbabaee, A.A., 2015. "Effects of rice husk biochar application on the properties of alkaline soil and lentil growth," Plant Soil Environ. 61, No. 11: 475-482

Alie, K., Abibatu, K., Mary, M., Mansaray P., and Sawyerr, A., 2014. "Effects of biochar derived from maize stover and rice straw on the germination of their seeds," American Journal of Agriculture and Forestry, 249. 
Antal, Jr., M.J. and Grönli, M., 2003. "The art, science, and technology of charcoal production," Industrial and Engineering Chemistry Research, 42(8): 1619-1640.

Aslam, Z., Khalid M., and Aon, M., 2014. "Impact of Biochar on Soil Physical Properties," Scholarly Journal of Agricultural Science, 4: 280-284

Atkinson, C.J., Fitzgerald, J.D. and Hipps, N.A., 2010. "Potential mechanisms for achieving agricultural benefits from biochar application to temperate soils," Plant and soil, 337 (1-2): 1-18.

Baldock, J. A., Smernik, R. J., 2002. "Chemical composition and bioavailability of thermally altered Pinus resinosa (red pine) wood," Organic Geochemistry, 33: 1093-1109.

Bhattacharjya, S., Chandra, R., Pareek N., and Kiran. P., 2015. "Biochar and crop residue application to soil: effect on soil biochemical properties, nutrient availability and yield of rice (Oryza sativa L.) and wheat (Triticum aestivum L.)," Archives of Agronomy and Soil Science.

Biederman, L.A. and Harpole, W.S., 2013. “ Biochar and its effects on plant productivity and nutrient cycling," GCB bioenergy, 5 (2): 202-214.

Carter, S., Shackley, S., Sohi, S., Boun Suy, T., and Haefele, S., 2013. " The Impact of Biochar Application on Soil Properties and Plant Growth of Pot Grown Lettuce (Lactuca sativa) and Cabbage (Brassica chinensis)," Agronomy, 3: 404-418

Chan, K.Y., Zwieten, L., Meszaros, I., Downie, A., and Joseph, S., 2008. "Using poultry litter biochars as soil amendments," Soil Research, 46 (5): 437-444.

Clough, T.J., Bertram, J.E., Ray, J.L., Condron, L.M., O'Callaghan, M., Sherlock, R.R., and Wells, N.S., 2010.
"Unweathered wood biochar impact on nitrous oxide emissions from a bovineurine-amended pasture soil," Soil Science Society of America Journal, 74 (3): 852-860.

DeLuca, T. H., 2016. "Influence of Biochar on Soil Nutrient Transformations, Nutrient Leaching, and Crop Yield," Advances in Plants and Agriculture Research, 4 Issue 5

Gao, T., Gao, M., Peng, J., and Li, N. (2018, July). Effects of Different Amount of Biochar on Nitrogen, Phosphorus and Potassium Nutrients in Soil. In IOP Conference Series: Materials Science and Engineering (Vol. 394, No. 2, p. 022043). IOP Publishing.

Karhu, K., Mattila, T., Bergström, I. and Regina, K., 2011. "Biochar addition to agricultural soil increased $\mathrm{CH} 4$ uptake and water holding capacity-results from a short-term pilot field study," Agriculture, Ecosystems and Environment, 140(1): 309-313.

Kloss, S., Zehetner, F., Dellantonio, A., Hamid, R., Ottner, F., Liedtke, V., Schwanninger, M., Gerzabek, M.H. and Soja, G., 2012. "Characterization of slow pyrolysis biochars: effects of feedstocks and pyrolysis temperature on biochar properties," Journal of environmental quality, 41 (4): 9901000

Krishnakumar, S., Rajalakshmi, A.G., Balaganesh, B., Manikandan, P., Vinoth, C. and Rajendran, V., 2014. "Impact of Biochar on Soil Health," International Journal Of Advanced Research, 2, Issue 4: 933-950

Lehmannn, J., Rillig, M., Thies, J., Masiello, CA., Hockaday, WC., Crowley, D., 2011. "Biochar effects on soil biota".

Meena, Rp., Karanam, V., Tripathi, S.C., Jha, A., Sharma, R. K., Singh, G. P. (2019). Irrigation management strategies in wheat for efficient water use in the 
regions of depleting water resources. "Agricultural Water management", 214, 38-46.

Mishra, A., Taing, K., and Shinogi, Y., 2017. "Effects of rice husk and rice husk charcoal on soil physicochemical properties, rice growth and yield, "Agricultural Science," 8: 1014-1032.

Mukherjee, A. and Lal, R., 2013. "Biochar Impacts on soil physical properties and greenhouse gas emissions," Agronomy, 3: 313-339.

Rosa, De. La., and Knicker, H, J.M., 2011. "Bioavailability of $\mathrm{n}$ released from $\mathrm{N}$ rich pyrogenic organic matter: An incubation study," Soil Biol. Biochem., 43: 2368-2373.

Sanchez-Garcia, M., Cayuela, M. L., Rasse, D., and Sánchez-Monedero, M. A. (2019). Biochars from Mediterranean agro-industry residues: physicochemical properties relevant for $\mathrm{C}$ sequestration and soil water retention. ACS Sustainable Chemistry and Engineering.

Sarfraz, R., Hussain, A., Sabir, A., Fekih, I. B., Ditta, A., and Xing, S. (2019). Role of biochar and plant growth promoting rhizobacteria to enhance soil carbon sequestration-a review. "Environmental Monitoring and Assessment", 191(4), 251.
Țenu, I., Melnic, I., Roșca, R., and Cârlescu, P. (2019). Research on the impact of tillage operations for autumn wheat crop set up over some soil properties. "Stiinta Agricola", (2), 122-127.

Thavanesan, S., and Seran, T. H., 2018. "Effect of Rice Straw and Husk Biochar on Vegetative Growth and Yield Attributes of Oryza sativa L," International Journal of Crop Science and Technology 4, Issue 2.

Wang, L., Xue, C., Nie, X., Liu, Y., and Chen, F. (2018). Effects of biochar application on soil potassium dynamics and crop uptake. Journal of Plant Nutrition and Soil Science, 181(5), 635-643.

Wu, P., Cui, P., Alves, M. E., Peijnenburg, W. J., Liu, C., Zhou, D. and Wang, Y. (2019). Interactive effects of rice straw biochar and $\gamma-\mathrm{Al}_{2} \mathrm{O}_{3}$ on immobilization of $\mathrm{Zn}$. "Journal of Hazardous Materials".

Younis, U., Ahmad, M. S., Farooq, Q. M., Hasnain, R. S. M., Naeem, S. A., and Mahmood, S., 2015. "Biochar affects growth and biochemical activities of fenugreek (Trigonella corniculata) in cadmium polluted soil," Journal of Applied Botany and Food Quality 88: $29-33$

\section{How to cite this article:}

Rema Barman, Akul Gupta and Geeta Kandpal. 2019. Combined Application of Biochar with Fertilizers Influence available Nitrogen, Phosphorus and Potassium Quantity in Soil. Int.J.Curr.Microbiol.App.Sci. 8(05): 1218-1224. doi: https://doi.org/10.20546/ijcmas.2019.805.138 